\title{
Chapter Ten
}

\section{Outstation Incorporation as Precursor to a Prescribed Body Corporate ${ }^{1}$}

\author{
Katie Glaskin
}

On my first journey to northern Dampierland Aboriginal communities in 1994, many members of those communities spoke to me about 'making a claim'. I had travelled there to speak with Bardi and Jawi peoples about the native title claim a group of elders had legally instructed the Kimberley Land Council to begin preparing on their behalf. ${ }^{2}$ Within a short time I realised that when people spoke to me about 'making a claim', and when I spoke with them about the native title claim, we were referring to different matters. They were speaking about outstations and the process of incorporation under the Commonwealth Aboriginal Councils and Associations Act 1976 (ACAA); I was talking about a claim to native title under the Commonwealth Native Title Act 1993 (NTA). The conflation many people subsequently made, between 'making a claim' to form an outstation group and 'making a claim' for native title, had its basis in their experiences of the outstation movement.

The outstation movement amongst Bardi and Jawi has resulted in a large number of small incorporated outstation groups, while a determination of their native title claim requires the formation of a single larger incorporated group, a Registered Native Title Body Corporate. The latter is defined either as a Prescribed Body Corporate (PBC) or as a body corporate registered on the National Native Title Register. ${ }^{3}$ A Registered Native Title Body Corporate holds native title on trust (as in a PBC) or acts 'as an agent or representative of the common

\footnotetext{
1 An earlier version of this chapter is embedded in my PhD thesis (Glaskin 2002). For their contribution to the overall development of that work, I am grateful to Francesca Merlan, Ian Keen, and Tim Rowse. To James Weiner for comments on an earlier draft of this chapter, to Bardi and Jawi people who have shared so much of themselves with me since 1994, and to Geoffrey Bagshaw with whom I worked on their native title claim since that time, I am also extremely grateful. The fieldwork on which this chapter is based would not have been possible without the support of the Kimberley Land Council and The Australian National University. I am grateful to them and to the Berndt Foundation at the University of Western Australia, which awarded me a postdoctoral fellowship that enabled me to further develop this work.

2 This claim was heard by the Federal Court of Australia in 2001 and 2003, and the court delivered its native title determination on 10 June 2005.

${ }^{3}$ See Subsections 193(2)(d)(iii) and (iv) and Section 253 of the NTA (reprinted as at 27 July 1998).
} 
law holders in respect of matters relating to native title' (NTA Section 58(a)). ${ }^{4}$ For the purposes of this chapter, I shall focus on PBCs incorporated under the ACAA.

This chapter is concerned with the relationship between two different kinds of incorporation among Bardi and Jawi peoples of Western Australia. Outstations are a means by which people can live on their country; native title is a mechanism by which people seek legal recognition of their relationships to country. Both require incorporation and are concerned at some level with indigenous connections to country. At issue here are not just the relationships between different kinds of Aboriginal corporations formed in response to different legislative requirements, but the consequences for the expression and enactment of property relations amongst those concerned. To what extent are these successive corporatising regimes an expression or transformation of those customary relations to land that they are constituted to represent in some sense, and how might such developments affect or influence one another?

This chapter is based on fieldwork conducted at various times between the years 1994 and 2001, prior to the determination of the Bardi and Jawi native title claim in June 2005. ${ }^{5}$ It does not, therefore, address post-determination efforts and discussions concerning $\mathrm{PBC}$ establishment; rather, it is concerned with the processual relationship between these kinds of incorporation as they emerged prior to a determination of native title. Notwithstanding this, I would expect that many of these same issues would emerge post-determination, and that the form of the determination itself is likely to have created additional issues with respect to $\mathrm{PBC}$ formation. ${ }^{6}$

\section{Background}

The area considered in this chapter is located in the northwest Kimberley region of Western Australia. It includes the northern tip of the Dampierland Peninsula (north of the Beagle Bay Reserve) and the islands in the King Sound to the west of Sunday Strait, the area over which Bardi and Jawi made their native title claim. ${ }^{7}$ There are three main communities within the claim area - Lombadina, Djarindjin and One Arm Point - which are also incorporated under the ACAA. Lombadina was a Pallottine Catholic mission that began as an outpost of Beagle

4 Fingleton (1994: 5-6) identifies the main functions of a PBC under the NTA, which include: entering into agreements with the government, whether for the surrender of native title (s.21(1)(a) and (3)), authorisation of future Acts (s.21(1)(b)), or to enter into local or regional agreements (s.21(4)); to participate in negotiations regarding grants of mining rights over native title land (s.29(1) and (2), s.31(1)(a) and (b), s.33); to be consulted about access to native title lands (s.26(4)(c)); to exercise procedural rights with respect to compulsory acquisition (s.23(6)); to deal with compensation issues (s.61 and s.51(6)); and to apply for variation of native title determinations (s.61). See Memmott et al. (this volume) for further discussion.

5 Sampi $v$ State of Western Australia [2005] FCA 777.

6 As of 10 July 2006 this decision was under appeal before the Full Federal Court of Australia.

7 The islands were not included in the determination of native title made on 10 July 2005. 
Bay Mission to its south in $1910 .^{8}$ In the 1980s, local politics within Lombadina led to the formation of Djarindjin community. This is situated immediately adjacent to Lombadina, and the two communities are distinguished mainly by the fence that divides them, separate corporations (and hence community councils), and their own community stores. ${ }^{9}$ Sunday Island Mission was originally formed as a non-denominational Protestant mission in 1899, and was transferred to United Aborigines Mission control in 1923. ${ }^{10}$ Bardi and Jawi were still coming into these missions up until the late 1920s at least, and even then, many people did not remain sedentary at the missions but moved between them and a number of white pearlers' camps. Such movement meant that the populations at these missions did not become settled until after World War Two (Robinson 1973: 175). Following a period of dislocation in Derby in the 1960s when Sunday Island Mission was closed, Bardi and Jawi who had formerly lived at the island established the community at One Arm Point in 1972. ${ }^{11}$

Bardi and Jawi movements into these missions in the early days had both voluntary and involuntary aspects. 'Coming in', as a number of Bardi people have referred to this movement, initially occurred as news spread that rations were available at the missions, and ultimately became a practical necessity in a changing economic landscape. Once a number of people were congregated at the missions, being near kin provided additional impetus for bush people to 'come in' to the missions. These centralisation movements occurred slowly. The movement of Sunday Island Mission residents to Derby occurred more quickly, and under greater coercion, as the mission was closed and school-aged children from the mission were taken to Derby and were subsequently followed by their parents. ${ }^{12}$ Coombs (1974) discussed Bardi and Jawi movement from Derby back to Sunday Island, and the ultimate formation of One Arm Point community, as an early example of the 'decentralisation trend'. Although this movement began as a process of individuals splintering from a centralised group, within a short time nearly all the Bardi and Jawi from Sunday Island Mission, who had been living in Derby, were living at One Arm Point. In that sense, while it was a disaggregation in terms of Bardi and Jawi moving away from other Aboriginal groups in the reserves at Derby, the movement is better understood as a return by those people who had been in exile from their country. All of these movements, however, can be seen as 'symptomatic of an inherent tension in Aboriginal accommodation to European presence' (Sullivan 1996a: 27). The

8 For further information regarding the establishment and founding of Lombadina, see Durack (1997).

9 They share a school and a health clinic.

10 For a detailed discussion of the formation of Sunday Island Mission, see Robinson (1973).

11 See Drysdale and Durack (1974) and Coombs (1974) for further discussion of the early establishment of One Arm Point community.

12 This was not just the case with respect to Sunday Island. Jebb (2002: 254-5) says that when Kimberley Aboriginal children from pastoral stations were taken to school in Derby by Native Welfare, they were similarly followed into the town by their parents. 
outstation movement, a movement away from the major communities, is not dissimilar in this respect.

While the outstation movement can be considered, as it is by Coombs (1974), as a 'decentralisation trend' (and this is true of both its spatial and administrative aspects, since it has resulted in the multiplication of incorporated outstation groups), it also has a centralising aspect. As the processes of incorporation (under the $A C A A$ ) and the economic means through which outstations can be established originate outside the indigenous community, the apparent dispersal of groups conceals a more complete political centralisation with respect to administrative and incorporative processes. Nevertheless, since one of the effects of the movement is to create multiple indigenous corporations, each with its own chairperson, set of rules and so on, with this caveat in mind, I continue to consider the outstation movement as decentralising in terms of intra-indigenous relationships and political authority.

\section{The Outstation Movement}

In parts of the Kimberleys, usually those where outstations are excised from large pastoral leases, Aborigines refer to excisions as 'matchboxes' because of their small size. When speaking in a possessive sense Bardi most commonly refer to an outstation as a 'block'. The outstation or homelands movement has been a visible trend amongst Aborigines in many parts of Australia for at least three decades (Coombs et al. 1980: 1). As well as returning to traditional country, Aborigines have chosen to form small outstation groups to avoid social problems in larger communities. ${ }^{13}$ The timing of the trend was concurrent with the provision of welfare benefits to Aboriginal people (Smith 2000: 62), and with government policy shifts, from assimilation to self-determination (later self-management) formulated in the late 1960s and early 1970s (Coombs et al. 1980: 5; Altman 1986: 477).

There are significant differences between outstation movements in different regions of Australia. Sexton (1996) compares the outstation movement in the Northern Territory and Western Australia, concluding that one of the most significant differences is in relation to the tenure of the land available for outstations. In the Northern Territory, the operation of the Commonwealth Aboriginal Land Rights (Northern Territory) Act since 1976 has resulted in the return of significant amounts of land to Aboriginal people. Aborigines who successfully claim land under the Act obtain a title that is an estate in fee simple (Sexton 1996: 5). Altman (1987: 1818) similarly identifies 'a correlation between the growth of the outstation movement and security of tenure' gained under

13 For example, Sullivan (1996a: 25) refers to movements by Aborigines from Warmun (Turkey Creek) to set up independent camps on Alice Downs, Frog Hollow and Glen Hill 'without facilities' in the mid-1970s, as moving away from destructive and disruptive social processes in the larger community. 
this Act in the Northern Territory. In Western Australia, where there was no land rights legislation prior to the NTA, secure tenure of this kind was not available. Many outstations were formed on vacant Crown Land (now called 'unallocated' Crown Land). Some were excised from pastoral leases, in which case the outstation group obtained a Special Purpose Lease for periods of 25-50 years, though these 'guarantee free entry to the holders of a mining tenement' (Sexton 1996: 6). The third possibility was for an Aboriginal group to obtain a 99-year lease from the Aboriginal Lands Trust, although in the northern Dampierland Peninsula these seem usually to be issued in relation to the creation of Aboriginal reserves under the Western Australian Aboriginal Affairs Planning Authority Act 1972 (such as the One Arm Point reserve), rather than outstations. The consequences of the Western Australian system were that Aboriginal land was 'much more a product of government discretion' than in the Northern Territory, with its statutory regime for claiming land (Sexton 1996: 6).

There are regional differences in outstation movements within states as well as between them. In the Kimberley region, there are marked differences in the outstation movement between Bardi and other nearby groups. While there are outstations south of Bardi in the Beagle Bay Reserve among Nyul Nyul and Jabirr Jabirr peoples, and south of Broome among Yawuru and Karajarri peoples, the density of outstations in these regions is not the same as amongst Bardi. ${ }^{14}$ The factors Smith (2000: 450) identifies with respect to variation in the outstation movement in the Coen region - local organisation, the environment and historical factors - are equally salient to the explanation of such differences between Bardi and other nearby groups.

In Western Australia the outstation movement has been in progress since the 1980s, and in 1999 there were some 225 outstations across the state (Muir 1999: 11). The outstation movement coincided with an era in which Aborigines began to receive wages or cash welfare payments instead of rations, and the transition 'from rations to cash' reflected 'a change in the rationalities of government, from tutelary/pastoral to liberal/contractual' (Rowse 1998: 86). In remote communities, integration into the cash economy was accompanied in many instances by the transition from mission-dominated institutions to secular self-governing towns, resulting in a 'dramatic shift in the nature, structure and moral economy of these Aboriginal communities' (Peterson 1998: 109).

Moizo relates the introduction of the Community Development Employment Projects (CDEP) scheme in Fitzroy Crossing to the movement of Fitzroy Aborigines

14 According to a 1994 ATSIC listing of incorporated groups in the ATSIC Kullari region (which encompasses this area), there were a total of 18 incorporated outstation groups in the region extending south of the Bardi and Jawi claim area to Bidyadanga, over a north-south distance of approximately $250 \mathrm{~km}$. In contrast, during the same period, there were at least 33 outstations in the Bardi and Jawi claim area, a north-south distance of approximately $60 \mathrm{~km}$. 
out of the town and into smaller (outstation) communities. ${ }^{15}$ He says that this movement occurred 'since they had the opportunity to be financially autonomous, an opportunity that did not exist prior to the introduction of $\mathrm{CDEP}^{\prime}$, which was implemented in Fitzroy Crossing in 1988 (Moizo 1990: 36). CDEP provides an important source of income for outstations, and this is augmented by pension monies, one-off grants, and cash earned through various means (Altman 1986: 478; Spicer 1997: 32-3; Smith 2000: 397). In 2005, government debate about the economic viability of remote Aboriginal communities was specifically linked with a view that communal landownership and lack of economic opportunities for remote area Aboriginal people were causally linked (Dodson and McCarthy 2005).

\section{Outstation Establishment}

In the Bardi and Jawi claim area, in common with many outstations in Western Australia, living areas are not large areas and do not 'confer much actual land or control on Aboriginal people' (Sexton 1996: 7). The outstations I was able to measure on the basis of land tenure documents are $5223 \mathrm{~m}^{2}, 7782 \mathrm{~m}^{2}, 1.5 \mathrm{ha}$, and just over 2 ha, and this appears to cover the usual size range. ${ }^{16}$ By way of comparison, the communities of One Arm Point and Djarindjin have leases covering areas of 14339.5 ha and 56727 ha respectively. ${ }^{17}$ Sullivan (1996a: 26) says that, on average, outstations in the Kimberley are of $1 \mathrm{~km}^{2}(0.405$ ha or 4050 $\mathrm{m}^{2}$ ) in size.

During the latter half of the 1980s, the first of the outstations in the Dampier Peninsula became incorporated under the Aboriginal Councils and Associations Act.

The provisions of the Act relate to a residential group in the area, not the owning group. They confer control over very limited aspects of the life of the group, are subject to very intrusive intervention prior to incorporation by the Registrar of Aboriginal Corporations and encourage non-Aboriginal procedures for representation and decision-making (Sullivan 1997: 18, emphasis added).

Funding grants through various government agencies were available to incorporated groups to assist with the establishment of outstation infrastructure,

15 Sanders (1998: 145) describes CDEP, a scheme that began in March 1977, as an attempt to 'put in place a more appropriate arrangement for remote Aboriginal communities than standard individualised UB [unemployment benefit] payment. This more appropriate arrangement was justified by an analysis of difference.' The arrangement, as Moizo (1990: 36) describes it, reduces the number of Aborigines on unemployment benefits by requiring Aborigines 'to do several hours of work per week in order to get an amount of money similar to that which they would receive on unemployment benefits'.

16 One outstation is as large as $8.0089 \mathrm{ha}$, and the exceptionally sized outstation in the region is 405.3871 ha (Pender Gardens in the southern portion of the claim area).

17 These are One Arm Point Reserve 20927 and Djarindjin Aboriginal Corporation, Dampier Location 297. 
such as bores or rain tanks, energy panels or generators, basic housing facilities, and outstation vehicles. ${ }^{18}$ The absence of recognised land rights in Western Australia meant that outstation groups were dependent on government support of this kind, since mining companies were not obliged to make financial contributions or compensation to indigenous landholders (Sullivan 1996a: 29). Regular outstation income then is derived from specific purpose grants, pensions or CDEP funding. ${ }^{19}$ Muir's description of the economy on which outstations in Western Australia have generally been built accurately portrays the situation I am familiar with in the peninsula:

The people moving to outstations were often registered as participants in CDEP projects of the larger communities. These people then remained on the larger communities' CDEP programs, with the outstation allocated as a specific CDEP project. The CDEP wage meant that people had an income and were able to purchase essential capital items ... As outstations developed, became permanent and incorporated under the Aboriginal Councils and Associations Act 1976 (Cwlth), they were, formally, able to secure separate funding from ATSIC for essential services like water, housing and continued CDEP support (Muir 1999: 11-12).

The outstation economies in this region then are based on a mixture of subsistence through fishing and hunting, with some gathering, social security payments (including pensions) and CDEP monies. Some outstations derive further income from commercial trochus exploitation, aquaculture, and tourism.

\section{A Place of One's Own: The Politics of Land Tenure}

Since outstation groups become incorporated under the $A C A A$, applications for incorporation go to the Registrar of Aboriginal Corporations and must include a copy of the proposed rules of the corporation. Sullivan says that 'while the rules may be based on Aboriginal custom (s. 43(4)), they need to address a number of matters ... many of which have no counterpart in Aboriginal custom or may be contrary to it'. These include the requirement for the corporation to make rules regarding meetings (there is a requirement for Annual General Meetings), and to keep a register of members, of which there must be at least twenty-five (Sullivan 1996b: 16-17).

After addressing a number of requisite criteria, including that of incorporation, applications for land to form an outstation are submitted to the Aboriginal Affairs Planning Authority which administers the Aboriginal Affairs

\footnotetext{
18 These are now available through the Office of Indigenous Policy Coordination, and were formerly available through the now-defunct Aboriginal and Torres Strait Islander Commission (ATSIC) and its precursor, the Department of Aboriginal Affairs.

19 See Sanders (1998) for a discussion of the basis and development of the scheme. The process of incorporation required outstation groups to submit plans for outstation specific CDEP.
} 
Planning Authority Act that established the Aboriginal Lands Trust. One criterion was to demonstrate that the applicants had traditional attachment to the area in question, although the corroborating documentation required was not substantial. $^{20}$ Such documentation could include genealogies prepared by anthropologists, by resource agency workers (who generally assisted with all facets of the incorporation process), or by the applicants themselves. Assertions regarding traditional attachment to the area could be augmented by supplying the local language name of the area as well as brief comments about the connections of the applicants to the area. Such requirements have been neither extensive nor prescriptive, and they have not been tested nor made subject to the kinds of proof of connection to country that is ultimately required by the NTA. So, while some parallel could be drawn between these two processes on the basis that both involve traditional affiliation with country, the very real differences between the two mean that the parallel cannot be sustained to any great extent.

Local shire councils also scrutinise applications for outstations, because of the implications of service delivery to remote communities. ${ }^{21}$ Local community councils also have a role in the approval of outstation areas, where proposed outstation areas fall within their lease jurisdictions. The process of groups seeking community council approval to form an outstation on an area of land seems to occur prior to the more formalised processes associated with incorporation and the Aboriginal Lands Trust application. Even this is likely to be preceded by informal consultations with other Aboriginal people with attachment to the area in question. ${ }^{22}$ Once a group has been incorporated and its outstation area has been approved by the Trust (and subject to these other processes), applications for funding the outstation group are submitted to the relevant funding body. ${ }^{23}$

In the absence of land rights legislation in Western Australia prior to the NTA, most Bardi family groups have sought to secure an outstation on their country. As a result, numerous outstations now exist within a very small region. Figure 10-1 represents the general locations of outstations within the Bardi and

20 Under the heading 'Customary Tenure', Section 32 of the Aboriginal Affairs Planning Authority Act refers at 32(1) to 'Aboriginal inhabitants of that area, being persons who are or have been normally resident within the area, and their descendants'. At 32(2) the Act says that: 'Regulations made in relation to an area to which subsection (1) applies may provide for the compilation, maintenance, and use of documentary evidence as to the entitlement of persons to any interest in the use of, or benefit to be derived from, specific areas of land or in the enjoyment of natural resources related to customary land use.'

21 With respect to outstation policy, the 25 June 1992 minutes of the Shire of Halls Creek in the East Kimberley included that 'the applicant is required to provide details as to their traditional association with the land' (Crough and Christophersen 1993: 137). The Shire resolved that they would not 'be responsible for the provision and maintenance of any services' (ibid).

22 Amongst Bardi, failure to consult with relevant landowners would usually have ramifications, including for community council members who were held responsible for allocating the land.

23 At the time of my research, this body was ATSIC. As at 2006, such applications for funding would be handled by the Office of Indigenous Policy Coordination. 
Jawi claim area. ${ }^{24}$ These outstations are all located quite close to the major communities, and to each other, and are typically situated within a small walking distance from the coast. This spatial distribution is reflective of Bardi and Jawi local organisation, which itself also reflects upon the environment - the availability of fresh water sources along the coast, as opposed to the hinterland - and the narrowness of the Dampierland Peninsula at its northernmost end.

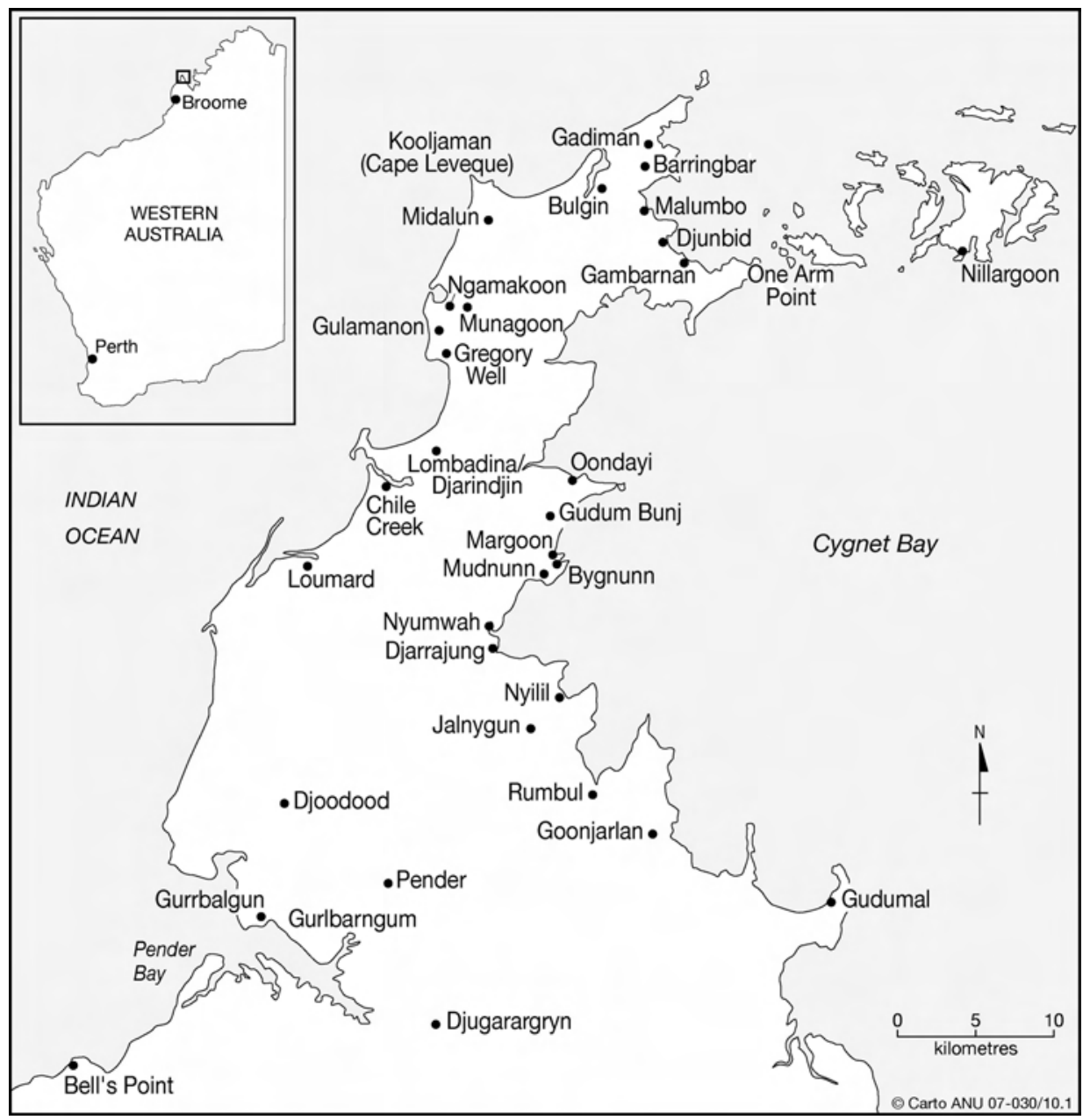

Figure 10-1: Approximate location of outstation groups in 2001.

24 The orthography in this figure is that used by the incorporated outstation groups. The most distant outstation is approximately $50 \mathrm{~km}$ away from one of the major communities, while most outstations would be roughly within a $20 \mathrm{~km}$ radius or less of these communities. 


\section{Local Organisation}

Bardi and Jawi share a system of local organisation comprised of estate groups centred on freshwater sources on the mainland coast or islands. The interior of the Dampierland Peninsula, which lies between Bardi estate groups, does not contain permanent water and is characterised as nimidiman (shared) country, or nimidiman jugara buru ('together possessing country') (Bagshaw 1999: 48), analogous to the notion of shared commons (see Burton, this volume). Bardi and Jawi are primarily affiliated with estates through patrifiliation: paternal adoption (andala) can similarly confer primary estate affiliation (Bagshaw 1999: 58). An individual's 'own' country (their buru) is therefore considered to be the buru of their father (and father's father). Individuals also have significant rights in their maternal estate (ningarlm) and in their spouse's estate (gurirriny). However:

In all matters pertaining to their respective ningarlm and gurirriny, individuals are expected to defer to estate-affiliates (i.e. those identified with the estate through patrifiliation). They are also expected to 'back up' the latter on estate-related issues ... (Bagshaw 1999: 62).

Effectively, rights in mother's country (ningarlm) and spouse's country (gurirriny) are not considered to be of the same primary order as those in father's country (buru). Bagshaw writes that while the land component of estates 'is typically quite small' (around 6 and $4.5 \mathrm{~km}^{2}$ in two mapped examples), 'the offshore areas of a bur may ... be quite extensive' (ibid: 49). Tidally exposed areas contiguous with the land are considered part of an estate, as are nearby offshore features such as islands, rocks, sandbanks, reefs and shallow waters (Bagshaw and Glaskin 2000: 5). Bagshaw (1999, 2001a, 2001b) identifies 21 extant Bardi buru, four extant Jawi buru, and six deceased estates within the Bardi and Jawi claim area. The deceased estates are in various stages of succession. The general locations of these buru are represented in Figure 10-2.

Hiatt (1996: 13-35) summarises the anthropological arguments that have historically occurred regarding the concept of clan, horde and band. Clan groups are not the same as residential groups; the latter consist of people related to each other by various means, and common descent in the male line, the criterion of estate (clan) affiliation, is only one of these. Bardi outstation groups frequently reflect and are premised on estate ownership, but similarly, the residential groups formed at outstations do not correlate entirely with them.

Bardi and Jawi consider the main requisite criteria of a person's ability to establish an outstation in a particular location within the terms of their own system of land tenure. Patrifiliates are considered to have every right to build an outstation in their own country, although senior patrifiliates are the people having greatest authority (or 'say') over that country and other members of the estate group should, in principle, defer to them. Outstations within the Bardi 
and Jawi claim area have largely (though not entirely) been established by estate affiliates within their own buru, and consequently some estate affiliates have begun to use the terms referring to their estate (buru) and to their outstation ('block') interchangeably. ${ }^{25}$ Since there are very few people in the Bardi and Jawi claim area with 'historical' rather than traditional associations to country, historical attachment (as opposed to traditional affiliation) has not been a significant issue in the allocation of land for outstations to date. Some Aborigines who were neither Bardi nor Jawi grew up at either Sunday Island or Lombadina, but these cases are few. Typically, where these cases do occur, the family or person with the historical attachment has approached patrifiliates from the estate where they would like to build their outstation for permission to do so.

Where individuals have a non-Bardi or non-Jawi father, and have not been 'grown up' by a Bardi or Jawi father, they often emphasise other lines of descent in order to reckon their connection to country. ${ }^{26}$ Some individuals with Bardi mothers and non-Bardi fathers (who are therefore unable to reckon country through their father) have instead 'followed' their maternal grandfather (nyami) 'for country' - in other words, in reckoning matters of descent, and consequently in articulating rights in country. This sometimes produces considerable friction between people claiming rights to the same area through different mechanisms. Where estate affiliates are unable to form an outstation within their own country because the land is alienated, they too have sought to emphasise other means of connection to country in order to make claims within other buru. These strategies have implications for the politics of land tenure among Bardi and Jawi peoples, and these politics have become especially apparent within the context of the outstation movement.

Estate-affiliates are empowered to grant enduring, albeit limited, rights of access, residence and usufruct in respect of their own bur to unrelated or distantly related persons. Such rights (and their referents) are known as nimalj, a term which I gloss as 'authorized use' ... Birth at a place outside one's own bur is also generally believed to confer a range of inalienable nimalj rights (including rights of access, residence and usufruct) in that locality (Bagshaw 1999: 61).

\footnotetext{
25 This was evident in some evidence given by applicants during the 2001 Federal Court hearing of the Bardi and Jawi native title claim.

26 This is mainly relevant to marriages with non-indigenous people, but can also occur where the father is Aboriginal (but not Bardi or Jawi) but the individual feels more socially connected to Bardi and has therefore followed the mother 'for country'. Trigger (1987: 223) makes a similar comment with respect to choice of linguistic affiliation at Doomadgee.
} 


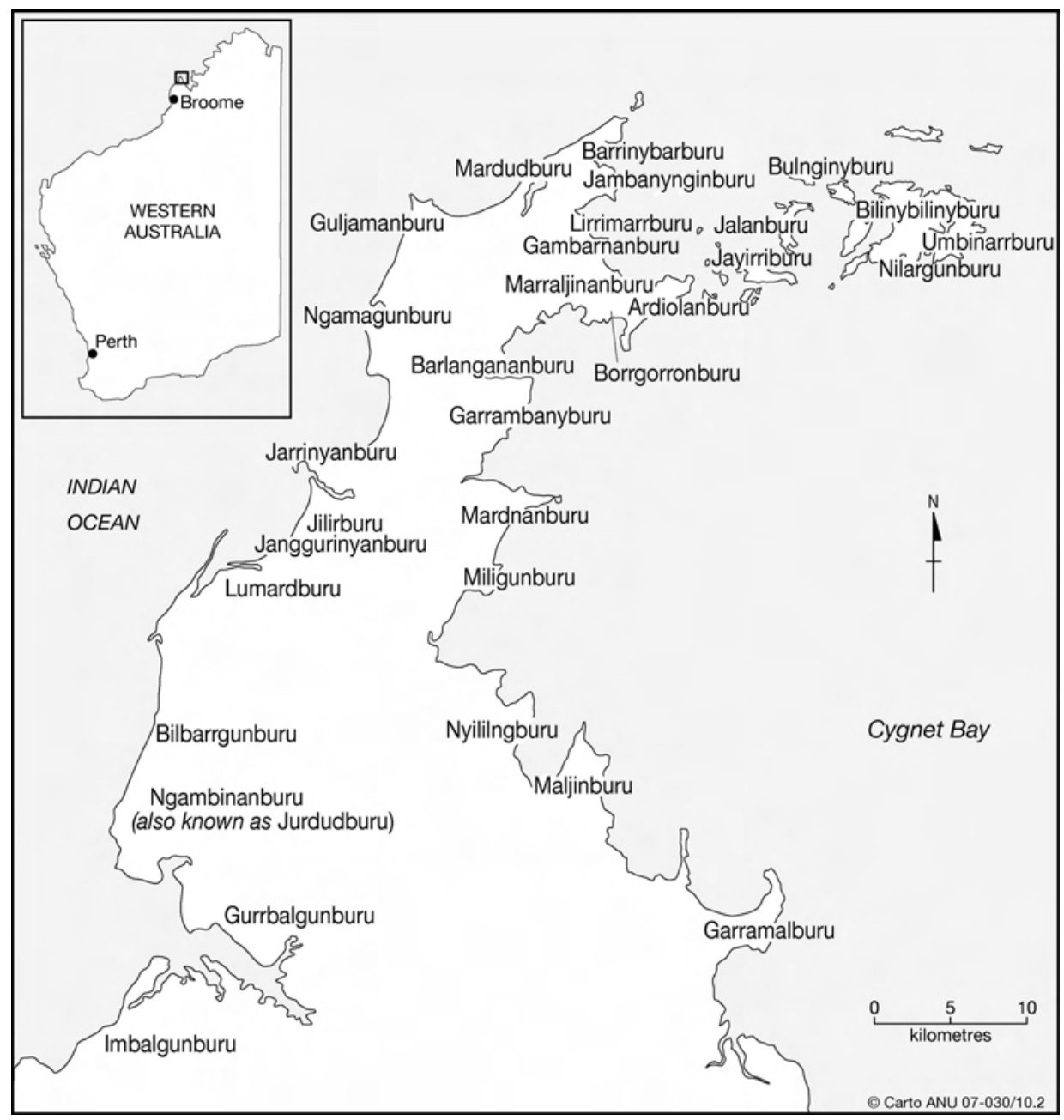

Figure 10-2: General locations of Bardi and Jawi buru.

Source: Bagshaw 1999, 2001b, 2001c.

When estate affiliates grant nimalj, it confers particular rights within a specified area of country to a person (the grantee) for the duration of their life. ${ }^{27}$ These rights may be as narrowly defined as the right to harvest bush fruit from a particular tree, or to mine ochre or fish at a certain location. As discussed, Bardi have a strongly held view regarding the primacy of the rights of estate affiliates within buru, and this is reflected in normative statements regarding principles of land tenure. Giving permission to others to set up an outstation is a contemporary corollary to giving nimalj to camp within that buru on an ongoing basis. Reflecting modern alterations of indigenous custom, verbal permission is

27 As Bagshaw (1999: 62) states, 'unless voluntarily relinquished by the recipient'. 
in some instances replaced by written permission. Difficulties arising between the respective parties - the grantor and the grantee - have increased the tendency towards written agreements, since conflict can arise when the individuals making the initial agreement pass away and these issues have to be negotiated by their descendants.

Sutton (1978: 125) describes the formation of outstations in the Cape Keerweer region as 'providing a source for an emerging group structure of a corporate type at a higher order of generality than was previously feasible'. Within the outstation movement, traditional land tenure is being articulated within a new political economy, one that involves aspects of 'intercultural production' (Merlan 1998). The nexus between the politics of land tenure and resource acquisition in this area is accentuated by the structural location of these matters within a 'whitefella' domain, involving various government agencies, programs, bureaucratic requirements in relation to procedure and expenditure, accountability measures, spot-checks on outstation groups, and so on. Such mechanisms pit outstation groups within the same region against one another symbolically, and in many instances materially as well. Claims to country in the context of the outstation movement, have, in my view, consolidated notions of the autonomy of these contemporary land-using groups. While there is a broad correlation between these outstations and buru (estate groups), that is, between some of the land users and the landowners (estate affiliates), this correlation is not complete; but where the correlation occurs, outstations are, in some cases at least, conflated with buru. These transitions could be considered 'a regenerated Aboriginal system of local tenure ... embedded within a different mode of material production', but which demonstrate 'strong continuities of the social and cultural modes of Aboriginal life including its political and territorial aspects' (Smith 2000: 442). Nevertheless, these transformations have implications for the emergence of new property relationships amongst Bardi in general, and within the context of a communal claim to native title.

\section{Prescribed Bodies Corporate}

Rowse's discussion of general principles underlying the incorporation of Aboriginal groups is equally apposite to a consideration of PBCs under the NTA.

As a strategy of reform, incorporation assumed an indigenous willingness to change, just as assimilation programs assumed, solicited and even coerced change in their clients. Incorporation must therefore be seen as an instance of continuity between assimilation and self-determination. Corporations, councils and associations are thoroughly 'Western' modes of collective action ... 'Self-determination' begs the question: what self or selves? (Rowse 2000: 132). 
Fingleton says that, since native title is a communal title, the rationale underlying the PBC includes it being the "contact point" for dealings between the native title holders and outsiders', so that:

The need for bodies corporate is explained partly by legal reasons the need for a legal entity with its own separate existence - and also by practical reasons (to facilitate dealings), and by a desire to protect the interests of individual members of the native title-holding group (1994: 3).

As Fingleton indicates, PBCs are designed, in large part, to facilitate external dealings between governments (and other interests) and native title-holding groups. Sansom (in Rowse 1993: 54) describes this succinctly: 'Leviathan addresses not Aborigines, but Aborigines Inc.' But, as Rowse says, 'mobs are not "corporations" whose anatomy can be given in terms of a series of offices and functions' (ibid: 55). Aboriginal social formations are not correlates of Western-style corporations. Political life within Aboriginal domains is characteristically dynamic, not particularly commensurate with the static corporate entity they are being asked to maintain.

The relationship between multiple incorporated outstation groups and a larger $\mathrm{PBC}$ (as a native title-holding body) is unlikely to emerge without some difficulty. While the outstation movement in this region can be seen, on the one hand, as both an exercise of people's native title and reflective of their traditional attachments to country, on the other hand, the implications of such incorporation in this area have been considerable. Relationships within communities have been impacted significantly as groups vie for allocation of resources, draw artificial boundaries around their incorporated groups, and use 'traditional' concepts to validate particular positions. Since the politics over land have become exacerbated in this context, the incorporation of the wider native title group as a PBC is likely to prove politically difficult, as I briefly describe below.

\section{Towards a Representative Structure}

In 1996 the Kimberley Land Council began working with the Bardi and Jawi claimant group on the development of a PBC. The claimant group's involvement in commercial developments on their country (such as tourism and trochus), and in non-commercial development of land through the outstation movement, meant that the right to negotiate under the NTA primarily involved negotiations between claimants rather than others outside of the claimant group. ${ }^{28}$

28 Under the NTA, prior to its amendment in 1998, once the National Native Title Tribunal had accepted and registered a native title claim, claimants held 'the right to negotiate' in relation to certain 'permissible future acts' within the claim area. Under Section 26, permissible future acts are 'essentially acts relating to mining, the compulsory acquisition of native title for the purpose of making a grant to a third party, and any other acts approved by the Commonwealth Minister'. The right to negotiate under the NTA was not the equivalent of a veto; rather, it allowed claimants and proponents of permissible future acts 
Accordingly, the claimant group needed to develop mechanisms through which negotiations over land management issues within the communal and legal context of native title could be addressed. This was necessary both for potential dealings with outsiders and for land and sea management issues arising between members of the claimant group. Management issues (such as the further development of outstations or the setting up of aquaculture projects) also held potential legal implications, since they could result in the issue of leases over land (or sea) that was under a native title claim. Since the right to negotiate required communal decisions about land interests which had not previously been negotiated internally in this manner, ${ }^{29}$ the development of a working group as a precursor to a $\mathrm{PBC}$ was closely related to the right to negotiate in this claim.

Decisions about land use had not previously been subject to this kind of formalised decision making by the broader Bardi and Jawi group. Rather, they had usually been made by the community councils, which were not necessarily or formally accountable to the wider jural public, although informal consultations with senior patrifiliates (where their country was concerned) and with madja or bosses (senior ritual leaders) were sometimes held. ${ }^{30}$ Madja (collectively madja-madjin) also frequently intervene in land use decisions in contexts where ngulungul (culturally restricted, 'sacred') locations are threatened by development. However, community council decisions have not necessarily taken into account the principles underlying the laws and customs of their peoples, and in this sense, their relationship with the $\mathrm{PBC}$ represents a significant issue. ${ }^{31}$

In late 1996 Bardi and Jawi established an interim working group to deal with matters requiring negotiation and to begin the work of consulting with the other native title holders about how their interests might best be represented in the structure of a PBC. The claimant group decided that their representative working group would comprise two representatives from each of the 'clan groups'. 'Clan groups' is a term that, especially since this time, has been increasingly applied by some claimants to the various regional aggregates defined by directional or geographic descriptions (rather than to estate groups). ${ }^{32}$

(the 'parties') to attempt to reach a negotiated agreement regarding the development or acquisition under consideration.

29 External negotiations have occurred with the Department of Conservation and Land Management (who sought to declare a nature conservation zone over part of the claim area); these negotiations were conducted via community meetings.

30 Madja is an Aboriginalisation of the English word 'master' and is equated with 'boss'.

31 These difficulties were already apparent in this area prior to 2002, as some of the community councils reacted against what they saw as a potential loss of power to the $\mathrm{PBC}$ - long before the latter entity had even been formed.

32 The working group members were chosen from the following 'clan groups': Mayala (which in this instance referred to Jawi from the islands east of Sunday Island); Iwanyun (Sunday Island Jawi); Inalabulu (islander Bardi); Ardiolan (northern Bardi); Gularrgon (western Bardi); Baniol (eastern Bardi); Banararr (north-eastern Bardi) and Guwarlgarda (southern Bardi). 
Although 'working group' meetings were designed primarily for nominated representatives, as many claimants attended these (between 1996 and 1998) as attended larger-scale native title meetings. There were a number of reasons why this was the case. Bardi and Jawi have a vital interest in anything potentially having bearing upon their country, and native title falls squarely within this ambit. In addition, the notion that members of the group could have their interests adequately represented by others was at odds with internal community politics and competitive status relations (see Trigger 1988). The political nature of social relationships within indigenous groups means that consensual decision making in the context of $\mathrm{PBCs}$ (and their formation) will require time. Decisions are likely to remain subject to 'an ongoing struggle over authority, legitimacy and influence between different groups and factions' (Martin and Finlayson 1996: 7). This means that even so-called 'consensual' decisions (Sutton 1984/5: 382) are likely to be subject to revision, especially where they deal with questions of landownership and resource use. Discussing the problems inherent in 'opinion formation and the problem of group consent', Sutton argues that:

European ideas of collective decision-making fall back naturally, almost unconsciously, on corporate notions which are different from those of Aborigines ... European corporate groups making major decisions, especially those with financial implications, have well-bounded memberships which may be publicly tested in an established neutral context (the courts). Aboriginal corporations, on the other hand, have customarily been reifications reflecting certain states of negotiation, in some cases blurred by chronic disputation for which no referral to external adjudication has been possible (ibid: 383-4).

In the Bardi and Jawi claimant group, politics within the group reflect the historical experiences of the members. ${ }^{33}$ These politics has been accentuated by the outstation movement, which has consolidated intensely localised interests and competition over the allocation of resources; they have typically centred upon whom has pre-eminent rights in buru, and as corollaries, who has the right to exploit specific resources in a buru (such as trochus), ${ }^{34}$ or more generally use that buru for tourism ventures. Such issues of connection to country, who is seen to have proprietorial rights in country, and hence can derive economic advantages most legitimately from that country, have tended to assume centre stage in negotiations over the formation of a representative working group and in discussions about their PBC.

33 See Glaskin (2002) for further discussion of this point.

34 The alngir (trochus) issue is a volatile resource issue among Bardi and Jawi, and is heavily implicated in the politics of country ownership. Foale and Macintyre (2000: 34) discuss reefs in West Nggela (Solomon Islands) as 'subjects of formal disputes', also as a consequence of the trochus industry. 


\section{Local Organisation in the Contemporary Context}

The 'atomic approach' (Sutton 1995: 1) to outstations evident amongst Bardi is reflective of their local organisation (density of estate groups), but I argue that this has been augmented in the current intercultural context. Many of the groups gaining outstations in this region have done so within their own buru, and they tend to see the establishment of their outstation as an outsider recognition of their traditional connections to that country. While outstation groups often reflect estate groups or their membership, they are not of themselves equivalent to them. The typical unit of outstation incorporation tends to be the extended family group, and Bardi either do not form incorporated groups on the basis of including all estate affiliates within those corporations or, if they do, they are usually unable to sustain such corporations (see Martin and Finlayson 1996: 7; Mantziaris 1997: 9). In these and other cases, as outstation groups have competed over control of outstation resources and the corporation, the groups have fractured and formed further outstations within the same buru. Over time, these choices people make about living arrangements (vis-à-vis the statutory arrangements that make funding for incorporated outstation groups possible) have the possibility of becoming naturalised. For example, Rigsby (1998: 35) has observed that individuals and groups may sometimes transform secondary rights into primary property rights over time in a variety of circumstances relating to succession, regencies and even land claim actions'. Sutton (1978: 126) makes the point that 'as the nature of secular property changes, corporate life will change, since it appears to be secular property which provides the most powerful constraints on fragmentation and unification'.

The outstation movement is considered as a 'decentralisation trend' (Coombs 1974) in spatial terms, since it involves the movement of people away from larger communities into smaller satellite communities. However, it can also be considered a decentralising movement in terms of the multiplication of Aboriginal corporations it has produced, each negotiating separately the institutional and administrative arrangements that are necessary to fund and develop outstation infrastructure. Although my discussion of native title incorporation has been on the processes preceding such incorporation (since this has not currently been realised among the Bardi and Jawi claimant group), the parallels and juxtapositions between these two processes should be apparent. Both the outstation movement and native title can be considered as providing new conditions of possibility for indigenous relationships to country to be formally expressed and recognised outside the indigenous domain, and both require incorporation.

However, one of the effects of decentralisation within the outstation movement, as I have argued, has been to consolidate notions of autonomy attaching to the outstation groups. This, along with differentiation within the 
claimant group consolidated by different historical experiences, and exacerbated by economics associated with resource use, has meant that it has been difficult for the claimant group to act as a corporate group. Rather, much claimant attention has focused primarily on either their own buru (estate) or on their own outstation. Particular rights in buru are embedded within a larger system which gives form to these local entitlements: an estate group could not reproduce itself but is system-dependent. Sutton (1996: 8) describes this as a 'whole-part dependency' in which the dependency is, on the one hand, 'between particular rights and interests and the wider system of jural and cultural practices in which they are embedded', but on the other hand, is 'between the rights and interests held in land or waters by subgroups or individuals, and the communal native title out of which they are "carved"' (see also Rigsby 1998: 24). While patrifiliates are considered to have the 'final say' with respect to estate matters, this is not generally considered to mean that they are able to deny matrifiliates, for example, their existing rights in those same areas. However, to the consternation of many other Bardi, at least some outstation groups were, during the period of my research, speaking and behaving as though their outstations were equivalent to private property, erecting fences and gates around them, effectively preventing (and denying) access by other Bardi to these areas. In addition, the persons who were preventing access during this time were not always patrifiliates.

\section{Conclusion}

Although Bardi and Jawi reached an agreement about a representative structure for a working group to precede their $\mathrm{PBC}$, during my research, this representation was consistently challenged from within the group. Incorporation within the outstation context resulted in the multiplication of incorporated outstation groups; but in the native title context, the requirement is for a single incorporated group, a PBC. The outstation movement has a centrifugal impetus, while native title, as in the $\mathrm{PBC}$ regulations, has a centripetal one. These two forces are invariably in tension with one another, and it remains to be seen, at some later stage, how the relationships between incorporated outstation groups and the PBC will be accommodated.

At issue here is the relationship between these corporate entities that are, in some sense, designed to give some external representation to indigenous landowners, and landownership itself.

If the core of property as a social institution lies in a complex system of recognized rights and duties with reference to the control of valuable objects, and if the roles of the participating individuals are linked by this means with basic economic processes, and if, besides, all these processes of social interaction are validated by traditional beliefs, attitudes, and values, and sanctioned in custom and law, it is apparent that we are dealing with an institution extremely fundamental to the 
structure of human societies as going concerns. For, considered from a functional point of view, property rights are institutionalised means of defining who may control various classes of valuable objects for a variety of present and future purposes and the conditions under which this power may be exercised (Hallowell 1955: 246).

In his determination of the Bardi and Jawi claim, Justice French commented on the distinction between the workings of property as a social institution at a broader level that is reproduced over time, and the internal differentiation of various rights within a claimant group that are fundamental to the workings of property. In relation to the Commonwealth's position that the determination of native title should be made at the level of the estate group, he said:

The Commonwealth argued against the applicants' position that the Bardi and Jawi people comprise the proper native title holding group and that the rights of patriclans, lawmen and others are to be determined intramurally [i.e., internally]. This position, it was said, involved a 'deliberate avoidance' of the requirements of the Act. The Act, it was said, requires the Court to specify who has what rights under traditional law and custom and not to delegate that question to the applicants. The Commonwealth position so expressed risked conceptual confusion between native title rights and interests held in common by a particular society and their distribution and exercise according to elements of a unitary traditional law and/or custom which may be ambulatory and responsive to changing circumstances without affecting the integrity of its normative foundations. ${ }^{35}$

Discussions concerning the level at which native title should be recognised in various jurisdictions will no doubt continue. Different levels of incorporation may reflect, to uneven extents, the different levels at which land is traditionally held (and sometimes the internal differentiation of these). The difficulties indigenous groups encounter in forming PBCs may be considerable, and the implications for social relations within indigenous groups have yet to fully emerge or be understood. Regardless of the form in which native title is determined, and the extent of rights and interests such determinations recognise (Glaskin 2003), Aboriginal groups will be required to form PBCs to hold and administer title or to enact agreements, and this will require internal negotiations within native title claimant groups. At the core of many of these internal negotiations are the claimant group's own property relations, that is, the social relations that they have among each other with respect to their exercise of rights in land or to speak for land. These internal property relations are distinct from those native title rights and interests that may eventually be recognised in native

35 Sampi v State of Western Australia [2005] FCA 777, at para 983. 
title determinations, but as I have argued elsewhere (Glaskin 2002, 2005), participation in the native title process itself (of which determinations of native title and incorporation as PBCs are part) will ultimately have an effect on the articulation and enactment of the internal property relations within those groups concerned.

\section{References}

Altman, J.C., 1986. 'Aboriginal Outstation Communities: Some Economic Issues.' Submission to the House of Representatives Standing Committee on Aboriginal Affairs, 20 November 1985. In Official Hansard Report (Vol III) of the House of Representatives Standing Committee on Aboriginal Affairs. Canberra: Government Printer.

, 1987. 'Aboriginal Outstation Communities: Further Economic Issues.' Further submission to the House of Representatives Standing Committee on Aboriginal Affairs, 10 February 1987. In Official Hansard Report of the House of Representatives Standing Committee on Aboriginal Affairs. Canberra: Government Printer.

Bagshaw, G.C., 1999. 'Native Title Claim WAG 49/98 (Bardi and Jawi): Anthropologist's Report.' Report prepared for the Kimberley Land Council on behalf of the native title claimants, February 1999.

, 2001a. 'Bardi and Jawi Supplementary Anthropology Report Parts 1, 2 and 3.' Filed in the Federal Court of Australia, Western Australia District Registry, General Division, in Sampi v State of Western Australia, WAG 49/1998, 27 August 2001.

_ 2001b. 'Applicants' Additional Anthropological Report Concerning Distribution and Spatial Extent of Local Estates (Bur[u]) Within the Bardi and Jawi Native Title Claim Area.' Filed in the Federal Court of Australia, Western Australia District Registry, General Division, in Sampi v State of Western Australia, WAG 49/1998, 8 February 2001.

and K. Glaskin, 2000. 'Anthropologist's Supplementary Report: Aspects of Bardi and Jawi Marine Tenure and Resource Usage.' Filed in the Federal Court of Australia, Western Australia District Registry, General Division, in Sampi $v$ State of Western Australia, WAG 49/1998, 30 October 2000.

Coombs, H.C., 1974. 'Decentralisation Trends Among Aboriginal Communities.' Department of Aboriginal Affairs WA Newsletter 1(8): 4-25.

, B.G. Dexter and L.R. Hiatt, 1980. 'The Outstation Movement in Aboriginal Australia.' Australian Institute of Aboriginal Studies Newsletter New Series 14: 1-8. 
Crough, G. and C. Christophersen, 1993. Aboriginal People in the Economy of the Kimberley Region. Darwin: Australian National University, North Australia Research Unit.

Dodson, M. and D. McCarthy, 2005. 'Customary Land as the Key for Future Development: Empower Those Who Want to Use Their Land and Protect Those That Don't.' Unpublished paper presented at the National Land Summit 'Land, Economic Growth and Development', Papua New Guinea University of Technology, Lae, 23-25 August 2005.

Drysdale, I. and M. Durack, 1974. The End of the Dreaming. Adelaide: Rigby.

Durack, M., 1997 (1969). The Rock and the Sand. Great Britain: Corgi.

Fingleton, J.S., 1994. 'Native Title Corporations.' Canberra: Australian Institute of Aboriginal and Torres Strait Islander Studies, Native Title Research Unit (Land, Rights, Laws: Issues of Native Title - Issues Paper 2).

Foale, S. and M. Macintyre, 2000. 'Dynamic and Flexible Aspects of Land and Marine Tenure at West Nggela: Implications for Marine Resource Management.' Oceania 71: 30-45.

Glaskin, K., 2002. Claiming Country: A Case Study of Historical Legacy and Transition in the Native Title Context. Canberra: Australian National University (PhD thesis).

— 2003. 'Native Title and the "Bundle of Rights" Model: Implications For the Recognition of Aboriginal Relations to Country.' Anthropological Forum 13: 67-88.

, 2005. 'Claim, Culture and Effect: Property Relations and the Native Title Process.' Paper presented at a workshop on 'Effects of Native Title', Centre for Aboriginal Economic Policy and Research, Australian National University, October.

Hallowell, A.I., 1955. Culture and Experience. Philadelphia: University of Pennsylvania Press.

Hiatt, L.R., 1996. Arguments About Aborigines: Australia and the Evolution of Social Anthropology. Cambridge: Cambridge University Press.

Jebb, M.A., 2002. Blood, Sweat and Welfare: A History of White Bosses and Aboriginal Pastoral Workers. Crawley: University of Western Australia Press.

Mantziaris, C., 1997. 'Beyond the Aboriginal Councils and Associations Act? Part 1.' Indigenous Law Bulletin 4(5): 10-14.

Martin, D.F. and J.D. Finlayson, 1996. 'Linking Accountability and Self-Determination in Aboriginal Organisations.' Canberra: Australian 
National University, Centre for Aboriginal and Economic Policy Research (Discussion Paper 116).

Merlan, F., 1998. Caging the Rainbow: Places, Politics and Aborigines in a North Australian Town. Honolulu: University of Hawai'i Press.

Moizo, B., 1990. 'Implementation of the Community Development Employment Scheme in Fitzroy Crossing: A Preliminary Report.' Australian Aboriginal Studies 1: 36-40.

Muir, K., 1999. 'Back Home to Stoke the Fires: the Outstations Movement in Western Australia.' Indigenous Law Bulletin 4(19): 11-14.

Peterson, N., 1998. 'Welfare Colonialism and Citizenship: Politics, Economics and Agency.' In N. Peterson and W. Sanders (eds), op. cit. and W. Sanders (eds), 1998. Citizenship and Indigenous Australians: Changing Conceptions and Possibilities. Cambridge: Cambridge University Press.

Rigsby, B., 1998. 'A Survey of Property Theory and Tenure Types.' In N. Peterson and B. Rigsby (eds), Customary Marine Tenure in Australia. Sydney: University of Sydney (Oceania Monograph 48).

Robinson, M.V., 1973. Change and Adjustment Among the Bardi of Sunday Island, North-Western Australia. Perth: University of Western Australia (MA thesis).

Rowse, T., 1993. After Mabo: Interpreting Indigenous Traditions. Melbourne: Melbourne University Press.

- 1998. 'Indigenous Citizenship and Self-Determination: The Problem of Shared Responsibilities.' In N. Peterson and W. Sanders (eds), op. cit.

- 2000. Obliged to be Difficult: Nugget Coombs' Legacy in Indigenous Affairs. Cambridge: Cambridge University Press.

Sanders, W., 1998. 'Citizenship and the Community Development Employment Projects Scheme: Equal Rights, Difference and Appropriateness.' In N. Peterson and W. Sanders (eds), op. cit.

Sexton, S., 1996. 'Homeland Movement: High and Low Roads.' Aboriginal Law Bulletin 3(83): 4-7.

Smith, B.R., 2000. Between Places: Aboriginal Decentralisation, Mobility and Territoriality in the Region of Coen, Cape York Peninsula (Queensland, Australia). London: University of London (PhD thesis).

Spicer, I., 1997. 'Independent Review of the Community Development Employment Projects (CDEP) Scheme.' Available from: http://www.atsic.gov.au/programs/noticeboard/CDEP/Spicer_Report/contents.asp 
Sullivan, P., 1996a. All Free Man Now: Culture, Community and Politics in the Kimberley Region, North-Western Australia. Canberra: Australian Institute of Aboriginal and Torres Strait Islander Studies.

- 1996b. 'The Needs of Prescribed Bodies Corporate Under the Native Title Act 1993 and Regulations: A Report on the Issues and Options.' In Final Report: Review of the Aboriginal Councils and Associations Act 1976 - Volume 2: Supporting Material, August 1996. Canberra: Australian Institute of Aboriginal and Torres Strait Islander Studies.

- 1997. 'A Sacred Land, A Sovereign People, an Aboriginal Corporation: Prescribed Bodies and the Native Title Act.' Casuarina: Australian National University, North Australia Research Unit (Report 3).

Sutton, P., 1978. Wik: Aboriginal Society, Territory and Language at Cape Keerweer, Cape York Peninsula, Australia. Brisbane: University of Queensland (PhD thesis).

- 1984/5. 'Opinion Formation and the Problem of Group Consent.' Anthropological Forum 5: 382-384.

- 1995. 'Atomism Versus Collectivism: The Problem of Group Definition in Native Title Cases.' In J. Fingleton and J. Finlayson (eds), Anthropology in the Native Title Era: Proceedings of a Workshop. Canberra: Australian Institute of Aboriginal and Torres Strait Islander Studies.

— 1996. 'The Robustness of Aboriginal Land Tenure Systems: Underlying and Proximate Customary Titles.' Oceania 67: 7-29.

Trigger, D.S., 1987. 'Languages, Linguistic Groups and Status Relations at Doomadgee, an Aboriginal Settlement in North-West Queensland, Australia.' Oceania 57: 217-238.

, 1988. 'Equality and Hierarchy in Aboriginal Political Life at Doomadgee, North-West Queensland.' Anthropological Forum 5: 525-543. 